Article

\title{
Amorphous ferric oxide as a hole-extraction and transfer layer on nanoporous bismuth vanadate photoanode for water oxidation
}

\author{
Ling Qian a, Pengfei Liu a, Le Zhang a , Chongwu Wang a, Shuang Yang a , Lirong Zheng ${ }^{\text {, }}$ \\ Aiping Chen ${ }^{\mathrm{a}, *}$, Huagui Yang a, * \\ a Key Laboratory for Ultrafine Materials of Ministry of Education, School of Materials Science and Engineering, East China University of Science and \\ Technology, Shanghai 200237, China \\ b Beijing Synchrotron Radiation Facility, Institute of High Energy Physics, Chinese Academy of Sciences, Beijing 100049, China
}

\section{A R T I C L E I N F}

Article history:

Received 27 February 2017

Accepted 27 March 2017

Published 5 xxxxxx 2017

\section{Keywords:}

Ferric oxide layer

Amorphous

Bismuth vanadate

Photoanode

Oxygen evolution

\begin{abstract}
A B S T R A C T
An amorphous ferric oxide layer was prepared on a bismuth vanadate photoanode. This resulted in improved charge carrier separation and surface catalytic performance compared with the photoanode without the oxide layer. The photocurrent of the oxide-layer-containing photoanode was $2.52 \mathrm{~mA} / \mathrm{cm}^{2}$ at $1.23 \mathrm{~V}$ versus the reversible hydrogen electrode, in potassium phosphate buffer $(0.5 \mathrm{~mol} / \mathrm{L}, \mathrm{pH}=7.0)$. The amorphous ferric oxide layer on the photoanode contained low-valence-state iron species $\left(\mathrm{Fe}^{\mathrm{II}}\right)$, which enabled efficient hole extraction and transfer.
\end{abstract}

(C) 2017, Dalian Institute of Chemical Physics, Chinese Academy of Sciences. Published by Elsevier B.V. All rights reserved.

\section{Introduction}

The direct capture and storage of solar energy via the formation of chemical bonds is a promising approach to realizing alternative energy sources $[1,2]$. Various approaches for solar energy storage have been reported. Photoelectrochemical (PEC) water splitting is one of the most promising approaches for hydrogen evolution [3-5]. n-Type bismuth vanadate (Bi$\mathrm{VO}_{4}$ ) is a promising photoanode in PEC systems, because of its narrow bandgap, appropriate conduction band energy level, and sufficient abundance [6]. However, typical incident photon-to-current conversion efficiencies (IPCE) of unmodified $\mathrm{BiVO}_{4}$ have been unimpressive, because of the rapid recombination of photogenerated electron-hole pairs, poor electrical conductivity, and slow hole transfer kinetics for water oxidation. Much effort has focused on enhancing the performance of $\mathrm{BiVO}_{4}$-based water splitting, by coupling with dedicated electron collectors [7], oxygen-evolution catalysts (OEC) [8], and forming homo- or hetero-junctions [9]. A synergetic enhancement of surface reaction kinetics and bulk charge separation should be an ideal way to improve the PEC performance of $\mathrm{BiVO}_{4}$. Chang et al. [10] prepared $\mathrm{Co}_{3} \mathrm{O}_{4}$ nanoislands on $\mathrm{BiVO}_{4}$ to suppress the formation of recombination centers, but the coverage of $\mathrm{Co}_{3} \mathrm{O}_{4}$ on $\mathrm{BiVO}_{4}$ was insufficient for long-term performance.

In the current study, we prepared an amorphous ferric oxide layer $\left(\mathrm{FeO}_{x}\right)$ on a $\mathrm{BiVO}_{4}$ photoanode, to enhance the PEC performance of $\mathrm{BiVO}_{4}$. The resulting photoanode (denoted Bi-

\footnotetext{
*Corresponding author. Tel: +86-21-64251987; Fax: +86-21-64252127; E-mail: hgyang@ecust.edu.cn

\# Corresponding author. Tel: +86-21-64251987; Fax: +86-21-64252127; E-mail: apchen@ecust.edu.cn

This work was supported by the National Natural Science Foundation of China $(21373083,21573068)$, and Program of Shanghai Subject Chief Scientist (15XD1501300) and the Scientific Research Foundation for the Returned Overseas Chinese Scholars, State Education Ministry and Science Technology Commission of Shanghai Municipality (14JC1490900).
} 
$\mathrm{VO}_{4} / \mathrm{FeO}_{x}$ ) exhibited a photocurrent of $2.52 \mathrm{~mA} / \mathrm{cm}^{2}$ at $1.23 \mathrm{~V}$ versus the reversible hydrogen electrode (RHE) in $0.5 \mathrm{~mol} / \mathrm{L}$ potassium phosphate buffer $(0.5 \mathrm{~mol} / \mathrm{L}, \mathrm{pH} 7.0)$ under AM 1.5G simulated solar irradiation.

\section{Experimental}

\subsection{Chemicals}

Bismuth nitrate pentahydrate $\left(\mathrm{Bi}\left(\mathrm{NO}_{3}\right)_{3} \cdot 5 \mathrm{H}_{2} \mathrm{O}, 98 \%\right)$, dimethyl sulfoxide (DMSO), sodium hydroxide $(\mathrm{NaOH}, \mathrm{AR})$ and hexane were purchased from Sinopharm Chemical Reagent Co., Ltd. Vanadyl acetylacetonate (VO(acac)2, 99\%) was purchased from J\&K.

\subsection{Preparation of nanoporous $\mathrm{BiVO}_{4}$ photoanode}

The nanoporous $\mathrm{BiVO}_{4}$ photoanode was prepared in two steps: electrodeposition of a BiOI nanoarray, and subsequent conversion to nanoporous $\mathrm{BiVO}_{4}$ by annealing and soaking treatment. Typically, $0.4 \mathrm{~mol} / \mathrm{L} \mathrm{KI}$ solution $(0.4 \mathrm{~mol} / \mathrm{L})$ was adjusted to $\mathrm{pH}=1.7$ by adding $\mathrm{HNO}_{3}$. Then, $20 \mathrm{mmol}$ of $\mathrm{KI}$ was added to give a transparent orange-red solution. This solution was mixed with $20 \mathrm{~mL}$ of absolute ethanol (99.99\%) containing $0.23 \mathrm{~mol} / \mathrm{L}$ p-benzoquinone, and the resulting solution was vigorously stirred for $15 \mathrm{~min}$. Electrodeposition was carried out using a three-electrode system with a fluorine-doped tin oxide (FTO) substrate $(2.5 \mathrm{~cm} \times 1 \mathrm{~cm})$ as the working electrode, platinum foil $(2 \mathrm{~cm} \times 2 \mathrm{~cm})$ as the counter electrode, and a saturated $\mathrm{Ag} / \mathrm{AgCl}$ electrode as the reference electrode. Cathodic deposition was performed potentiostatically at $-0.1 \mathrm{~V}$ versus $\mathrm{Ag} / \mathrm{AgCl}$ at room temperature for $5 \mathrm{~min}$. $\mathrm{BiVO}_{4}$ electrodes were obtained by depositing $0.1 \mathrm{~mL}$ of a DMSO solution containing $0.4 \mathrm{~mol} / \mathrm{L} \mathrm{VO}(\mathrm{acac})_{2}$ on the BiOI film, followed by annealing in a muffle furnace at $450{ }^{\circ} \mathrm{C}$ for $2 \mathrm{~h}$. After soaking in $0.5 \mathrm{~mol} / \mathrm{L}$ $\mathrm{NaOH}$ solution for 30 min to remove excess $\mathrm{V}_{2} \mathrm{O}_{5}$, the resulting yellow $\mathrm{BiVO}_{4}$ film was rinsed in pure water and allowed to dry.

\subsection{Preparation of $\mathrm{BiVO}_{4} / \mathrm{FeO}_{x}$ photoanode}

Iron (III) 2-ethylhexanoate $(50 \%(w / w)$ in mineral spirits, $\mathrm{J} \& \mathrm{~K})$ was dissolved in hexane to give a $10 \%(w / w)$ solution. 5 $\mu \mathrm{L}$ of this solution was deposited onto the $\mathrm{BiVO}_{4}$ photoanode using a pipette. The electrode was irradiated by an ultraviolet light-emitting diode for $50 \mathrm{~h}$ to achieve decomposition of precursor complex, and was then annealed in an oven at $100{ }^{\circ} \mathrm{C}$ for $1 \mathrm{~h}$. A similar procedure was used to prepare the $\mathrm{FTO} / \mathrm{FeO}_{x}$ samples.

\subsection{Characterization}

The crystal structures of the samples were determined using X-ray diffraction (XRD, Bruker D8 Advanced diffractometer, $\mathrm{Cu} K \alpha$ radiation, $40 \mathrm{kV}$ ). The morphologies and microstructures of the samples were characterized by field-emission scanning electron microscopy (FESEM, Hitachi S4800, Japan) and high-resolution transmission electron microscopy (HRTEM,
JEOL JEM-2010F, F20, 200 kV).

\subsection{Photoelectrochemical measurements}

PEC experiments were conducted by back-side illumination using a three-electrode configuration. The sample electrode, platinum foil, and $\mathrm{Ag} / \mathrm{AgCl}$ in saturated $\mathrm{KCl}$ solution were used as the working, counter, and reference electrodes, respectively.

Simulated solar radiation was provided by a solar simulator (Oriel, 91160, AM 1.5 globe), the power of which was calibrated to be $100 \mathrm{~mW} / \mathrm{cm}^{2}$ using a Newport Oriel PV reference cell system (model 91150V). A potassium phosphate (KPi) buffer solution $(0.5 \mathrm{~mol} / \mathrm{L}, \mathrm{pH}=7.0)$ with and without $\mathrm{Na}_{2} \mathrm{SO}_{3}(1$ $\mathrm{mol} / \mathrm{L}$ ) as a hole scavenger was used as the electrolyte. The IPCE was measured by a solar simulator (Newport 70525) coupled with a filter (Newport 70625) and an aligned monochromator (Newport 7400). All experiments were performed using an electrochemical workstation (Parstat 2237, Princeton, UK).

Electrochemical impedance spectroscopy (EIS) measurements were carried out by applying an AC amplitude of $50 \mathrm{mV}$ with a frequency range from $10^{5}$ to $0.01 \mathrm{~Hz}$, in KPi buffer $(0.5$ $\mathrm{mol} / \mathrm{L})$ under the open-circuit potential. Mott-Scottky plots were obtained under the same solution and scanned from 0 to $1 \mathrm{~V}$ versus RHE. The AC potential frequency was $5000 \mathrm{~Hz}$ under dark conditions, with an amplitude of $3 \mathrm{mV}$.

The potential versus $\mathrm{Ag} / \mathrm{AgCl}$ was converted to the $\mathrm{RHE}$ scale using the Nernst equation:

$$
E_{\mathrm{RHE}}=E_{\mathrm{Ag} / \mathrm{AgCl}}+0.059 \times \mathrm{pH}+0.1976
$$

\section{Results and discussion}

Fig. 1(a) shows that the gossamer-like amorphous $\mathrm{FeO}_{x}$ was uniformly deposited on the surface of the $\mathrm{BiVO}_{4}$ nanoparticles, without obvious aggregation. Energy dispersive X-ray spectroscopy was used to confirm the presence of the ferric oxide layer (Fig. 1(b)). The mapping images show the uniform distri-
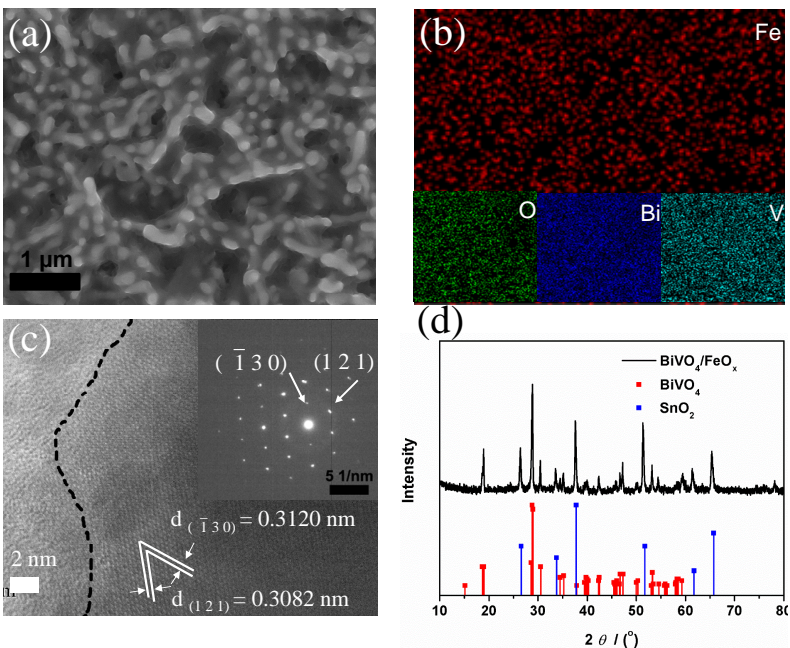

Fig. 1. (a) Top-view SEM image of the $\mathrm{BiVO}_{4} / \mathrm{FeO}_{x}$ photoanode; (b) Elemental mapping images of the $\mathrm{BiVO}_{4} / \mathrm{FeO}_{x}$ photoanode; (c) HRTEM image and corresponding SAED pattern of the $\mathrm{BiVO}_{4} / \mathrm{FeO}_{x}$ film; (d) XRD pattern of the $\mathrm{BiVO}_{4} / \mathrm{FeO}_{x}$ photoanode. 
bution of Fe throughout the $\mathrm{BiVO}_{4}$ nanoparticles. The selected area electron diffraction (SAED) pattern and HRTEM image in Fig. 1(c) indicated a lattice spacing of $\sim 0.31 \mathrm{~nm}$. The angle of $50^{\circ}$ between the two lattice fringes was consistent with the angle between the (130) and (121) planes. The crystal structure of $\mathrm{BiVO}_{4} / \mathrm{FeO}_{x}$ was investigated by XRD (Fig. 1(d)). Obvious diffraction peaks corresponded to monoclinic $\mathrm{BiVO}_{4}$, while diffraction peaks of $\mathrm{Fe}_{2} \mathrm{O}_{3}$ or $\mathrm{FeO}$ were not observed, confirming the presence of amorphous ferric oxide.

Fig. 2(a) shows current-potential curves of the $\mathrm{BiVO}_{4}$ and $\mathrm{BiVO}_{4} / \mathrm{FeO}_{x}$ photoanodes under back-side illumination. $\mathrm{FeO}_{x}$ is capable of evolving $\mathrm{O}_{2}$ in basic solution at moderate overpotentials [11], when not coupled with a semiconductor for photooxidation of water in neutral aqueous solution. Adding $\mathrm{FeO}_{x}$ enhanced the photocurrent over the entire potential range. The $\mathrm{BiVO}_{4} / \mathrm{FeO}_{x}$ photoanode exhibited an AM $1.5 \mathrm{G}$ photocurrent of $2.52 \mathrm{~mA} / \mathrm{cm}^{2}$ at $1.23 \mathrm{~V}$ versus RHE for water splitting. The photocurrent of the $\mathrm{BiVO}_{4}$ photoanode was $0.8 \mathrm{~mA} / \mathrm{cm}^{2}$.

Fig. 2(b) shows chronoamperometry measurements of the $\mathrm{BiVO}_{4} / \mathrm{FeO}_{x}$ and $\mathrm{BiVO}_{4}$ photoanodes at $0.6 \mathrm{~V}$ versus RHE, under chopped AM $1.5 \mathrm{G}$ simulated solar radiation at $100 \mathrm{~mW} / \mathrm{cm}^{2}$. Under irradiation, a photocurrent spike was observed for the $\mathrm{BiVO}_{4}$ photoanode at an applied potential of $0.6 \mathrm{~V}$ versus RHE.
This was due to the rapid generation and subsequent recombination of charge carriers. When irradiation ceased, an obvious cathodic transient was observed, which was caused by the accumulation of holes [12]. The cathodic and anodic transients were barely observed in the measurements for the $\mathrm{BiVO}_{4} / \mathrm{FeO}_{x}$ photoanode. This indicated that the $\mathrm{FeO}_{x}$ coating decreased charge recombination and hole accumulation in the $\mathrm{BiVO}_{4}$ surface [13]. This observation suggested that the recombination of photogenerated charge carriers was suppressed in the $\mathrm{Bi}$ $\mathrm{VO}_{4} / \mathrm{FeO}_{x}$ photoanode compared with in the $\mathrm{BiVO}_{4}$ photoanode [10].

EIS can provide information about the interfacial properties of electrodes. The diameter of the semicircle in the EIS curve indicates the electron transfer resistance within the electrode interface [14]. Fig. 2(c) shows typical EIS curves for the $\mathrm{BiVO}_{4}$ and $\mathrm{BiVO}_{4} / \mathrm{FeO}_{x}$ photoanodes under irradiation in KPi buffer. A smaller diameter was observed for the curve of the $\mathrm{BiVO}_{4} / \mathrm{FeO}_{x}$ photoanode under irradiation compared with the $\mathrm{BiVO}_{4}$ photoanode. This indicated that the resistance within the $\mathrm{FeO}_{x} /$ electrolyte interface was much smaller than that within the $\mathrm{BiVO}_{4}$ /electrolyte interface. Thus, the presence of $\mathrm{FeO}_{x}$ decreased the charge transfer barrier at the electrode interface, so the oxygen-evolution reaction was enhanced as reported pre-
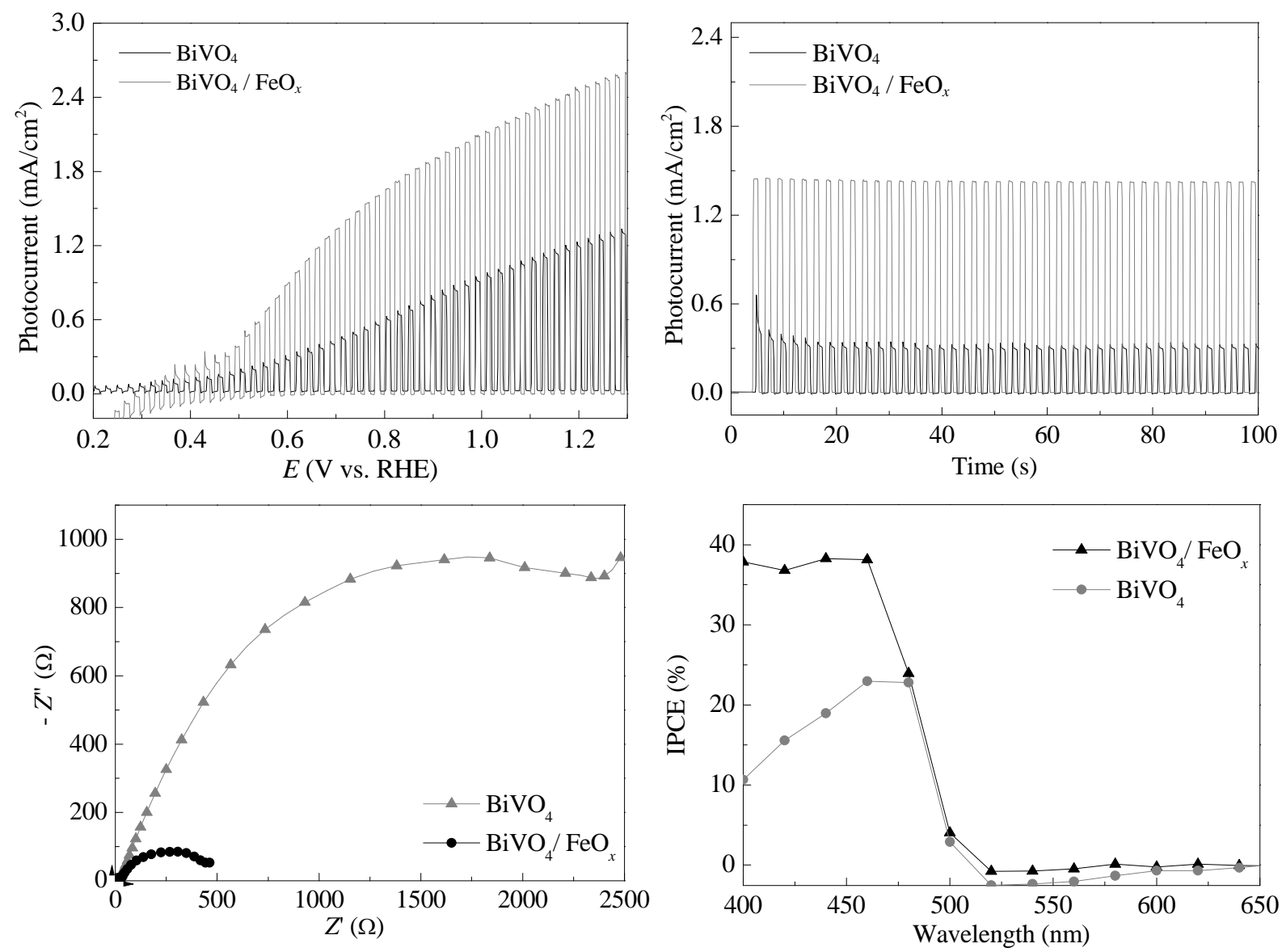

Fig. 2. (a) Current-potential curves of the $\mathrm{BiVO}_{4}$ and $\mathrm{BiVO}_{4} / \mathrm{FeO}_{x}$ photoanodes under $\mathrm{AM} 1.5 \mathrm{G}$ simulated solar radiation $\left(100 \mathrm{~mW} / \mathrm{cm}^{2}\right)$, in potassium phosphate buffer $(0.5 \mathrm{~mol} / \mathrm{L}, \mathrm{pH}=7.0)$. (b) Chronoamperometry measurements of the photoanodes at $0.6 \mathrm{~V}$ versus RHE, under AM $1.5 \mathrm{G}$ simulated solar radiation $\left(100 \mathrm{~mW} / \mathrm{cm}^{2}\right)$ in $0.5 \mathrm{~mol} / \mathrm{L}$ potassium phosphate buffer $(0.5 \mathrm{~mol} / \mathrm{L}, \mathrm{pH}=7.0)$. (c) Electrochemical impedance $\mathrm{spectra}$ of $\mathrm{BiVO}_{4} / \mathrm{FeO}_{x}$ and $\mathrm{BiVO}_{4}$ photoanodes under open-circiut potential in dark. (d) The incident photon conversion efficiencies of $\mathrm{BiVO}_{4} / \mathrm{FeO}_{x}$ and $\mathrm{BiVO}_{4}$ photoanodes at 1.23 V vs. RHE. 
viously [10]. Water oxidation occurred more readily because of the lower reaction barrier, so a cathodic shift was observed in the onset potential.

The IPCE values of the $\mathrm{BiVO}_{4} / \mathrm{FeO}_{x}$ and $\mathrm{BiVO}_{4}$ photoanodes are plotted as a function of wavelength in Fig. 2(d). The IPCE spectra of the $\mathrm{BiVO}_{4}$ and $\mathrm{BiVO}_{4} / \mathrm{FeO}_{x}$ photoanodes exhibited photoresponses up to $520 \mathrm{~nm}$. The $\mathrm{BiVO}_{4}$ photoanode exhibited a maximum IPCE of $11 \%$ at $400 \mathrm{~nm}$, while the $\mathrm{BiVO}_{4} / \mathrm{FeO}_{x}$ photoanode exhibited an IPCE of $38 \%$ at the same wavelength. The IPCE results indicated that the photocurrent response resulted from photon absorption solely by $\mathrm{BiVO}_{4}$ (i.e. no photon absorption by amorphous $\mathrm{FeO}_{x}$ ). Thus, the enhanced photochemical performance of the $\mathrm{BiVO}_{4} / \mathrm{FeO}_{x}$ photoanode was attributed to enhanced charge transfer and catalysis kinetics, rather than to enhanced light absorption.

The $\mathrm{FeO}_{x}$ layer was characterized by X-ray photoelectron spectroscopy (XPS), to understand its composition. The Bi $4 f$ state exhibited splitting peaks at 159.0 and $164.5 \mathrm{eV}$ (Fig. 3(a)), and the V $2 p$ state exhibited peaks at 516.9 and $523.9 \mathrm{eV}$ (Fig. $3(\mathrm{~b})$ ). Fig. 3(c) shows the XPS spectrum of the Fe $2 p_{3 / 2}$ and $2 p_{1 / 2}$ region for the $\mathrm{BiVO}_{4} / \mathrm{FeO}_{x}$ sample. The $\mathrm{BiVO}_{4} / \mathrm{FeO}_{x}$ sample exhibited an obvious satellite peak at around $716 \mathrm{eV}$, which corresponded to $\mathrm{Fe}^{\mathrm{II}}$ [15]. The $\mathrm{Fe} 2 p_{3 / 2}$ peaks of $\mathrm{Fe}^{\mathrm{III}}$ and $\mathrm{Fe}^{\mathrm{II}}$ were both centered at $\sim 711 \mathrm{eV}$. A satellite peak of the Fe ${ }^{\mathrm{III}}$ main line was observed at $\sim 719 \mathrm{eV}$, which indicated the presence of

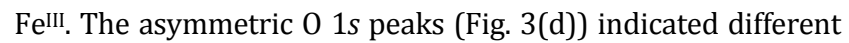
oxygen species present near the surface. Three $01 s$ binding
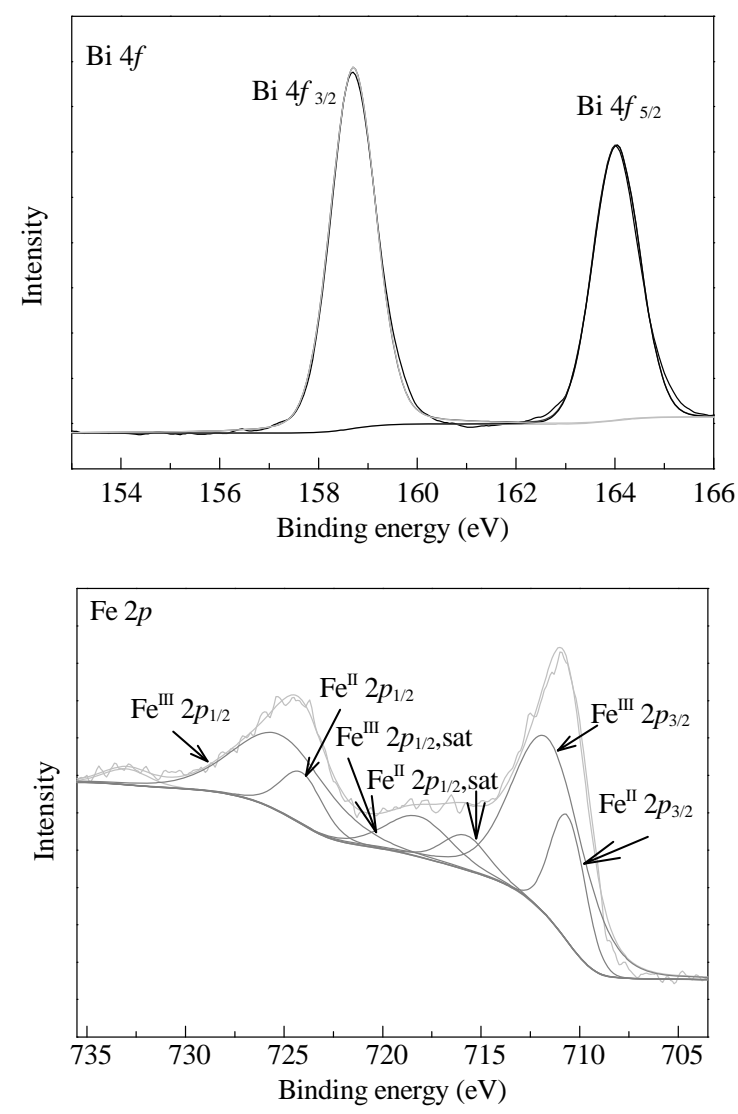

energies (529.3, 530.6 and $532.2 \mathrm{eV}$ ) were observed in the spectrum of the $\mathrm{BiVO}_{4} / \mathrm{FeO}_{x}$ sample, which were assigned to $\mathrm{O}^{2-}$ species in $\mathrm{FeO}, \mathrm{Fe}_{2} \mathrm{O}_{3}$, and adsorbed $\mathrm{H}_{2} \mathrm{O}$, respectively. These results suggested that Fe II sites formed in the amorphous $\mathrm{FeO}_{x}$. These $\mathrm{Fe}^{\mathrm{II}}$ sites acted as shallow donors for the layer of $\mathrm{FeO}_{x}$, which increased conductivity and promoted carrier transfer $[16,17]$.

To understand the role of FeII in the PEC process, X-ray absorption fine structure spectra were measured under ex-situ and in-situ conditions [18]. Fig. 4 shows the X-ray absorption near-edge structure (XANES) spectra. The edge position of $\mathrm{FeO}_{x}$ (7121.8 eV at half-height of the normalized edge-jump) was 1.2 $\mathrm{eV}$ lower than that of standard $\mathrm{Fe}_{2} \mathrm{O}_{3}$. This suggested a slightly lower oxidation state of $\mathrm{Fe}$ in the $\mathrm{BiVO}_{4} / \mathrm{FeO}_{x}$ film, compared with that in $\mathrm{Fe}_{2} \mathrm{O}_{3}$ (Fig. 4(a)). The shape of the XANES spectrum reflects the ligand type and coordination geometry of the X-ray-absorbing transition metal [19]. Compared with the spectrum of $\mathrm{Fe}_{2} \mathrm{O}_{3}$, the $\mathrm{FeO}_{x}$ spectrum was shifted to lower energy, but was otherwise similar. This suggested that the Fe coordination was largely similar to that in $\mathrm{Fe}_{2} \mathrm{O}_{3}$. In-situ XANES spectra were then recorded. Fig. 4(b) shows that under open-circuit conditions, the edge position of $\mathrm{FeO}_{x}$ was at $\sim 7121.8 \mathrm{eV}$, at half-height of the normalized edge-jump. After applying a bias of $1.2 \mathrm{~V}$ to the photoanode, the edge position exhibited a $0.6 \mathrm{~V}$ anodic shift compared with that of the photoanode under open-circuit conditions. Simultaneously irradiating and applying a $1.2 \mathrm{~V}$ bias to the photoanode caused the
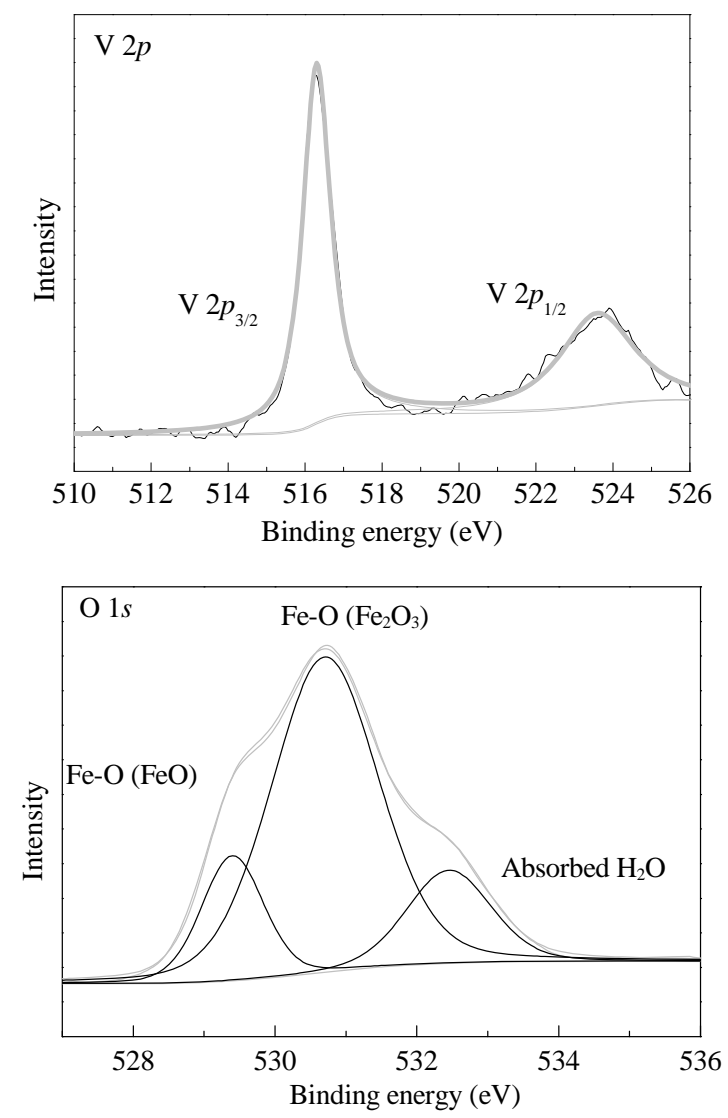

Fig. 3. XPS profiles of the (a) Bi $4 f$, (b) V $2 p$, (c) Fe $2 p$, and (d) $01 s$ regions for $\mathrm{BiVO}_{4} / \mathrm{FeO}_{x}$. The Fe (II satellite peak at 716 eV in the Fe $2 p$ region and the $01 s$ peak at $529.3 \mathrm{eV}$ indicated the presence of $\mathrm{Fe}^{\mathrm{II}}$. 

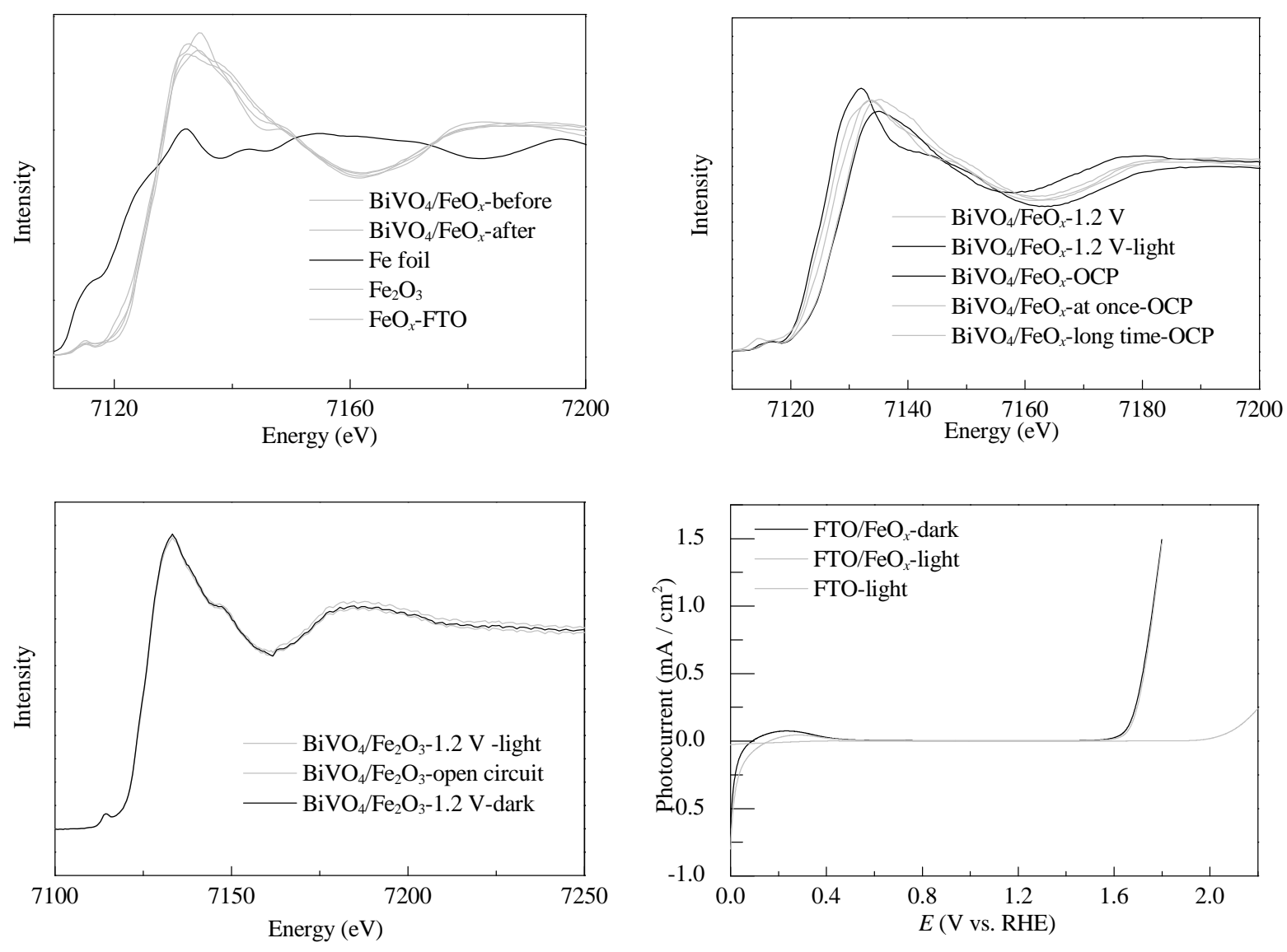

Fig. 4. (a) K-edge $\mathrm{XANES}$ spectra of $\mathrm{Fe}$ foil (grey), $\mathrm{Fe}_{2} \mathrm{O}_{3}$ (dark grey), $\mathrm{FeO}_{x}$ on $\mathrm{FTO}$ (red), and $\mathrm{BiVO}_{4} / \mathrm{FeO}_{x}$ before (black) and after (blue) irradiation and applied bias. (b) In-situ K-edge XANES spectra of $\mathrm{BiVO}_{4} / \mathrm{FeO}_{x}$ under $1.2 \mathrm{~V}$ bias (red), under $1.2 \mathrm{~V}$ bias and irradiation (orange), and under open-circuit conditions (black). (c) In-situ K-edge XANES spectra of $\mathrm{BiVO}_{4} / \mathrm{Fe}_{2} \mathrm{O}_{3}$ under $1.2 \mathrm{~V}$ bias (blue), under $1.2 \mathrm{~V}$ bias and irradiation (black), and under open-circuit conditions (red); (d) Current-potential curves of FTO under irradiation (blue) and $\mathrm{FTO} / \mathrm{FeO}_{x}$ in the dark (black) and under AM $1.5 \mathrm{G}$ simulated solar radiation $\left(100 \mathrm{~mW} / \mathrm{cm}^{2}\right.$, red $)$ in potassium phosphate buffer $(0.5 \mathrm{~mol} / \mathrm{L}, \mathrm{pH}=7.0)$.

edge position to anodically shift by $\sim 1 \mathrm{~V}$, compared with that of the sample under a bias of $1.2 \mathrm{~V}$. The shift in edge position indicated an in-situ change in the valence state with $\mathrm{FeO}_{x}$. This was consistent with the hole transfer process in the $\mathrm{FeO}_{x}$ layer during photochemical reaction. In-situ X-ray absorption spectra of the $\mathrm{BiVO}_{4} / \mathrm{Fe}_{2} \mathrm{O}_{3}$ film were also recorded. XANES spectra of the film prepared by annealing at $450{ }^{\circ} \mathrm{C}$ at a potential of $1.2 \mathrm{~V}$ are shown in Fig. 4 (c). The edge position of the $\mathrm{BiVO}_{4} / \mathrm{Fe}_{2} \mathrm{O}_{3}$ showed no change upon irradiation under an applied bias. To rule out the oxidation of Fe species under bias and irradiation without the contribution of $\mathrm{BiVO}_{4}$, linear scan tests of amorphous $\mathrm{FeO}_{x}$ in the dark and under irradiation were performed (Fig. 4(d)). The results indicated that oxidation occurred at $\sim 1.6 \mathrm{~V}$ versus RHE. Thus, a bias of $1.2 \mathrm{~V}$ versus RHE was insufficient to oxidize the Fe species.

These results suggested that photogenerated holes in $\mathrm{BiVO}_{4}$ could be captured and transferred at the ferric oxide layer. Scheme 1 shows how trace $\mathrm{Fe}^{\mathrm{II}}$ species played a subtle but profound role as a shallow dopant during the PEC process. Under irradiation and an applied bias, Fe ${ }^{\mathrm{II}}$ species were oxidized to $\mathrm{Fe}^{\mathrm{III}}$ or $\mathrm{Fe}^{\mathrm{IV}}$ by holes, and then acted as active sites for water oxidation. This could be considered a self-repair and self-activation recyclable reaction mode. The anodic shift in the
EXAFS edge position of the $\mathrm{BiVO}_{4} / \mathrm{FeO}_{x}$ photoanode under irradiation and bias was consistent with hole transfer in the amorphous ferric oxide layer (Scheme 1). The near absence of anodic or cathodic peaks indicated the high efficiency of hole transfer and catalysis in the presence of the $\mathrm{FeO}_{x}$ layer. When irradiation and the bias ceased, the edge positon of $\mathrm{FeO}_{x}$ reverted to the previous position. $\mathrm{Fe}^{\mathrm{II}}$ sites reportedly act as donors and therefore increase the density of charge carriers. The formation of $\mathrm{Fe}^{\mathrm{II}} / \mathrm{Fe}^{\mathrm{III}}$ mixed valence states could have significantly enhanced the conductivity, by way of the hopping mechanism [20].

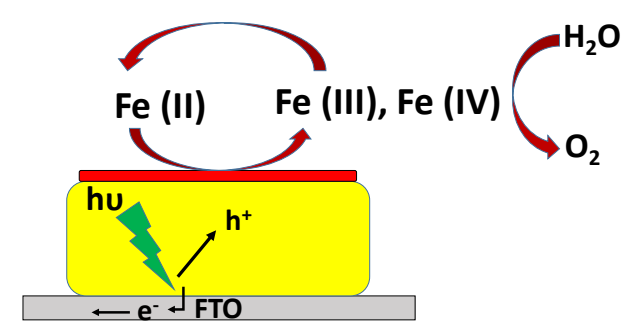

Scheme 1. Mechanism of charge separation for the $\mathrm{BiVO}_{4} / \mathrm{FeO}_{x}$ heterojunction. 


\section{Graphical Abstract}

Chin. J. Catal., 2017, 38: 0-0 doi: 10.1016/S1872-2067(17)62809-2

Amorphous ferric oxide as a hole-extraction and transfer layer on nanoporous bismuth vanadate photoanode for water oxidation

Ling Qian, Pengfei Liu, Le Zhang, Chongwu Wang, Shuang Yang, Lirong Zheng, Aiping Chen *, Huagui Yang *

East China University of Science and Technology; Institute of High Energy Physics, Chinese Academy of Science

An amorphous ferric oxide layer was deposited on bismuth vanadate in a photochemical process. Species in this layer enhanced charge carrier separation and surface catalytic performance.

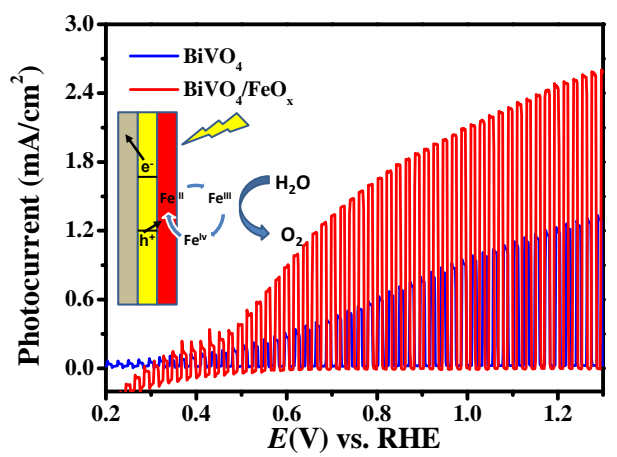

\section{Conclusions}

Forming an amorphous $\mathrm{FeO}_{x}$ layer on the $\mathrm{BiVO}_{4}$ photoanode significantly improved its photoactivity for water oxidation compared with the $\mathrm{BiVO}_{4}$ photoanode without the $\mathrm{FeO}_{x}$ layer. The $\mathrm{BiVO}_{4} / \mathrm{FeO}_{x}$ photoanode exhibited a photocurrent density of $2.5 \mathrm{~mA} / \mathrm{cm}^{2}$ at $1.23 \mathrm{~V}$ versus RHE. The enhanced photoactivity resulted from the increased conductivity and surface catalytic kinetics, which in turn resulted from the formation of Fe ${ }^{\mathrm{II}}$ sites. This study reports a simple and effective method for preparing photoactive $\mathrm{BiVO}_{4}$ for use in PEC water oxidation at low activation temperature, without requiring dopants.

\section{References}

[1] N. S. Lewis, Science, 2007, 315, 798-801.

[2] X. B. Chen, C. Li, M. Grätzel, R. Kostecki, S. S. Mao, Chem. Soc. Rev., 2012, 41, 7909-7937.

[3] A. Fujishima, K. Honda, Nature, 1972, 238, 37-38.

[4] A. J. Bard, Science, 1980, 207, 139-144.

[5] M. Grätzel, Nature, 2001, 414, 338-344.

[6] Y. Park, K. J. McDonald, K. S. Choi, Chem. Soc. Rev., 2013, 42, 2321-2337.

[7] L. T. Zhou, C. Q. Zhao, B. Giri, P. Allen, X. W. Xu, H. Joshi, Y. Y. Fan, L. V. Titova, P. M. Rao, Nano. Lett., 2016, 16, 3463-3474.

[8] T. W. Kim, K. S. Choi, Science, 2014, 343, 990-994.
[9] J. Z. Su, L. J. Guo, N. Z. Bao, C. A. Grimes, Nano Lett,, 2011, 11, 1928-1933.

[10] X. X. Chang, T. Wang, P. Zhang, J. J. Zhang, A. Li, J. L. Gong, J. Am. Chem. Soc., 2015, 137, 8356-8359.

[11] R. D. L. Smith, M. S. Prévot, R. D. Fagan, Z. P. Zhang, P. A. Sedach, M. K. J. Siu, S. Trudel, C. P. Berlinguette, Science, 2013, 340, 60-63.

[12] L. W. Zhang, E. Reisner, J. J. Baumberg, Energy Environ. Sci., 2014, 7, 1402-1408.

[13] H. Dotan, K. Sivula, M. Grätzel, A. Rothschild, S. C. Warren, Energy Environ. Sci., 2011, 4, 958-964.

[14] P. S. Bassi, S. Y. Chiam, Gurudayal, J. Barber, L. H. Wong, ACS Appl. Mater. Interfaces, 2014, 6, 22490-22495.

[15] K. J. Kim, D. W. Moon, S. K. Lee, K. H. Jung, Thin Solid Films, 2000, 360, 118-121.

[16] Y. C. Ling, G. M. Wang, J. Reddy, C. C. Wang, J. Z. Zhang, Y. Li, Angew. Chem. Int. Ed., 2012, 51, 4074-4079.

[17] Y. B. Kuang, Q. X. Jia, G. Ma, T. Hisatomi, T. Minegishi, H. Nishiyama, M. Nakabayashi, N. Shibata, T. Yamada, A. Kudo and Kazunari Domen, Nat. Energy, 2016, 2 (16191):1-6.

[18] D. Friebel, M. W. Louie, M. Bajdich, K. E. Sanwald, Y. Cai, A. M. Wise, M. J. Cheng, D. Sokaras, T. C. Weng, R. Alonso Mori, R. C. Davis, J. R. Bargar, J. K. Nörskov, A. Nilsson, A. T. Bell, J. Am. Chem. Soc., 2015, 137, 1305-1313.

[19] M. Risch, V. Khare, I. Zaharieva, L. Gerencser, P. Chernev, H. Dau, J. Am. Chem. Soc., 2009, 131, 6936-6937.

[20] N. Iordanova, M. Dupuis, K. M. Rosso, J. Chem. Phys., 2005, 122, 144305/1-144305/10.

\section{无定形氧化铁层在纳米多孔BiVO ${ }_{4}$ 的光电化学分解水反应中的作用

$$
\begin{aligned}
& \text { 钱 岭, 刘鹏飞 }{ }^{\mathrm{a}} \text {, 张 乐 }{ }^{\mathrm{a}} \text {, 王重午 }{ }^{\mathrm{a}} \text {, 杨 } \text { 双 }^{\mathrm{a}} \text {, 郑黎荣 }{ }^{\mathrm{b}} \text {, 陈爱平 }{ }^{\mathrm{a},{ }^{*}} \text {, 杨化桂 }{ }^{\mathrm{a},{ }^{*}} \\
& \text { 华东理工大学材料科学与工程学院超细材料教育部重点实验室, 上海 } 200237 \\
& \text { 中国科学院高能物理研究所北京同步辐射中心, 北京100049 }
\end{aligned}
$$

摘要: 通过“人工光合成”过程, 将太阳能转化成氢能的形式加以存储和利用, 是替代传统化石能源的清洁能源的制备有效 途径. 其中, 光电化学分解水是氢能制备的最有潜力的路径之一. $\mathrm{n}$ 型 $\mathrm{BiVO}_{4}$ 由于具有丰富的储量、较窄的带隙以及合适的 能带位置, 被称为光电化学领域的研究热点. 然而, 未修饰的 $\mathrm{BiVO}_{4}$ 光阳极性能并不理想, 主要原因在于载流子复合严重、 导电性差以及表面催化动力学低等性质的制约. 科研工作者们针对这些方面已进行了非常多的研究, 例如与电子传输层 的复合、产氧电催化剂的担载以及异质结的构建等. 其中表面动力学和电荷分离的同时提升是更理想的改善 $\mathrm{BiVO}_{4}$ 光阳极 
性能的方法. 我们在上述研究基础上, 采用光化学沉积法在纳米多孔 $\mathrm{BiVO}_{4}$ 电极表面担载无定形氧化铁层, 将电极在 $1.23 \mathrm{~V}$ vs. RHE电位下的光电流提升至 $2.52 \mathrm{~mA} / \mathrm{cm}^{2}$, 是初始光电化学性能的3倍. 采用间歇光照计时电流(i-t)测试, 电化学交流阻 抗谱(EIS), X射线光电子能谱(XPS), 原位和非原位的X射线精细结构能谱(in-situ and ex-situ XAFS)等表征手段研究了无定 形氧化铁层的成分和光电化学反应过程中的价态变化, 从而分析出光电化学性能提升的原因.

间歇光照i-t测试和EIS测试结果表明,无定形氧化铁沉积在BiVO 4 使电荷累积减少, 复合率降低. XPS测试结果发现无 定形氧化铁层存在少量的二价铁成分. 通过原位XAFS测试发现, $\mathrm{BiVO}_{4} / \mathrm{FeO}_{x}$ 电极中 Fe原子的价态在光照和施加外加偏压 条件下会有价态的升高, 而撤去光照和偏压后Fe原子的价态状态与最初非原位的测试结果重合. 这样的结果证明了无定 型氧化铁层在光电化学反应过程中由于二价铁成分的存在, 能够很好的通过价态改变实现空穴的吸附和传输, 即吸附空 穴, 被空穴氧化成三价或四价, 同时结合自身电催化活性, 促进表面分解水反应的进行. 而水的氧化反应结束时, 则伴随着 二价铁离子的再生成. 这种反应机理为开发更高效的电催化剂, 匹配光电极使用, 有着重大的指导意义.

关键词: 氧化铁层; 无定形; 钒酸铋; 光阳极; 氧生成

收稿日期: 2017-02-27. 接受日期: 2017-03-27. 出版日期: 2017-00-05.

*通讯联系人. 电话: (021)64251987; 传真: (021)64252127; 电子信箱: hgyang@ecust.edu.cn

\#通讯联系人. 电话: (021)64251987; 传真: (021)64252127; 电子信箱: apchen@ecust.edu.cn

基金来源: 国家自然科学基金(21373083, 21573068), 上海优秀学术带头人(15XD1501300)、教育部留学人员回国启动基金和上海 科学技术委员会(14JC1490900).

本文的英文电子版由Elsevier出版社在ScienceDirect上出版(http://www.sciencedirect.com/science/journal/18722067).

For Author Index:

QIAN Ling, LIU Pengfei, ZHANG Le, WANG Chongwu, YANG Shuang, ZHENG Lirong, CHEN Aiping, YANG Huagui 